\title{
Professional Employment Assistance Practices in Quebec's Carrefour Jeunesse-emploi: Bonding with Youths Distanced from the Labour Market and Leading Them to Action
}

\author{
Provenche Ysabel $^{1, *}$, Tremblay-Roy Julie ${ }^{2}$ \\ ${ }^{1}$ Professor, School of Social Work, Laval University, Québec, G1V 0A6, Canada \\ ${ }^{2}$ Graduate Student, School of Social Work, Laval University, Québec, G1V 0A6, Canada \\ *Corresponding Author: Ysabel.Provencher@svs.ulaval.ca
}

\begin{abstract}
Our article reports part of the findings of research conducted in Québec (Canada) with professionals employed by Carrefours jeunesse-emploi, a network of community organizations dedicated to employment participation of young people aged 16 to 35 (Provencher, Émond \& Tremblay-Roy, 2010). The study was an effort to generate knowledge about employment coaching, a practice that is now shared by the different professionals attached to public, private and community employment assistance networks in industrialized nations, against a ground of activated social assistance henceforth focused on the sustainable labour market participation of excluded populations. The study sought to document the practices of professionals in community employment assistance agencies and their influence in achieving the objectives of Quebec's participation policy. Analysis performed on 24 interviews conducted in the administrative jurisdictions of Quebec City and Charlevoix brought out three attitudes that are favoured when implementing coaching practices: helping young adults increase their self-knowledge and identify what they wish for themselves; respecting their pace in defining and reaching their goals, and being careful not to take action in their stead. These attitudes translate into two types of professional know-how or competencies: (1) creating a bond, and (2) leading young clients to take action. Findings from this research mirror conclusions in other studies showing that public employment policies are making front line workers responsible for developing, for each of their clients, the specific process that will best help them become labour market participants, and in effect, for building new social practices. On the whole, these findings confirm the pertinence of increasing our knowledge about the influence of employment services professionals in implementing public employment participation policies in industrialized nations.
\end{abstract}

Keywords Youth Employment Services, Job Insertion, Employment Professionals

\section{Introduction}

This article addresses the issue of professional qualifications in employment coaching as utilized by professionals in employment support services directed to marginalized young adults and/or those who are considered distanced from the labour market. More specifically, this article will account for part of the findings of a research project conducted with over twenty professionals in the Quebec's network of Carrefours jeunesse-emploi from the Québec City/Charlevoix region of Québec, a network of community organizations dedicated to labour force participation of youths aged 16 to 35 (Provencher, Émond \& Tremblay-Roy, 2010).The first part of the article explores 1) the transformation by industrialized countries of their assistance policies, to focus on the labour force participation of marginalized populations, and 2) the issue of employment coaching practices with troubled youth. Conceptual framework and methodology are covered in the second and third part of the article, while the fourth part deals with professional qualifications for employment coaching based on a review of practices.

Starting in the mid-1990s, research by most OECD countries into so-called passive income replacement policies led to thorough reforms of assistance plans, aligning them with a post-Fordian vision of the role of the state, which focuses on supporting a healthy labour market. The new "activated" assistance plans, which link income security, employment and labour market policies, work to foster sustainable labour market participation among assistance recipients. Operationalized according to various models and implemented in a variety of contexts by actors in the public, non-profit and private environments, the new assistance plans update the function of employment coaching or "reinforced follow-up" of unemployed individuals, and extends it to all employment service professionals (Gélot \& Nivolle, 2000; Provencher,2004,2007,2008,2013; Provencher \& Richard, 2010). 
These coaching practices are given concrete form in various programs, activities and participation measures offered to different assisted client groups. Drawing upon these regulated mechanisms and on an effective understanding of local labour market conditions and educational opportunities available, employment assistance service professionals pursue activities and build practices that are tailored to the particular circumstances of each person coached (Defalvard, Brun \& Thibault, 2008; Houzel, Outin \& Ramaux, 2000). Thus, while formal coaching procedures and structures create work guidelines for employment assistance service professionals, they do not entirely define their daily actions. These professionals develop collective know-how and strategies for the use of administrative regulations based on their judgment, experience and beliefs about the client groups served (Leclerc, Filteau \& Bourassa, 2002; Sandfort, 2000).

Some of the initial studies dealing with issues related to assistance plan reforms have brought to light the influence of front line agents in implementing these reforms. These studies addressed the attitudes and perceptions of employment professionals regarding beneficiaries, as well as the degree to which employability programs and services can foster sustainable participation in the labour market and/or ensure assistance recipients exit poverty (Brodkin, 1997; Bullock, 2004; Hagen \& Owens-Manley, 2002; Herd, Mitchell \& Lightman, 2005; Riccucci \& Lurie, 2003; Weissert, 1994).

Other studies have examined and described coaching activities carried out by public service employment agents. Some of these studies revealed for instance that professionals activate their social networks to secure information on job availability and to find jobs for clients (Baron, Bureau, Leymarie \& Nivolle, 1995; Livermore \& Neustrom, 2003). Other research brought forward professionals' views on the discrepancy between the mission of organizations that employ them and the resources available to these organizations. Indeed, the increasing number of clienteles using employment assistance services has resulted in an increase in workload, and the need for greater versatility to work as a coach (Bell, 2005; Goyette, Bellot \& Panet-Raymond, 2006; Leclerc, Filteau \& Bourassa, 2002).

On the whole, research has shown that coaching practices used by employment professionals are deployed in an environment governed by restrictions: limited budgets, political pressure, time constraints, and client demands (Baron, Dugué \& Nivolle, 2005; Bessy, Eymard-Duvernay, Gomel \& Simonin, 1995; Hagen \& Wang, 1993; Livermore \& Neustrom, 2003; MacDonald \& Marston, 2006; Meyers, Glasser \& MacDonald, 1998). In spite of the reforms, interaction between employment assistance officers and clients in public, private or non-profit employment services continues to occur in the same restrictive context, particularly with the issue of time management and the discrepancy between available resources and client demands or needs (Crif formation \& conseil, 2005; Goyette, Bellot \& Panet-Raymond, 2006; Hjörne, Juhila \&Van Nijatten, 2010).
Brodkin (1997)states that while specific practices are uniformly aimed at supporting sustainable labour market participation, they are shaped by various factors such as the agents' professional skills, job description, the resources available to the organization that employ them, the local job market, as well as motivations and intervention strategies that are part of the local organization's mandate, and so forth.

Research on employment assistance service providers has shown their profession to have a strong relational component that remains ill-defined inasmuch as it is exercised in a variety of organizations whose mandates continue to evolve(Bompard \& Daubech, 2000). In the meantime, while the coaching approach is defined nationally in policies and ensuing programs, it is expressed and implemented locally (Defalvard, Brun \& Thibault, 2008).

Transition to local implementation is an aspect that has rarely been studied systematically (Austin, Johnson, Chow, De Marco \& Ketch, 2009), leading us to wonder what kind of coaching models can be construed from a review of actual professional practices. Which underlying coaching principles are thus embodied? What are the organizational, economic, political and social factors that influence employment assistance service providers in building their professional practices? Presented here are partial findings of a study concerning a knowledge-generating process on the coaching practices of professionals employed by various organizations in the Réseau des Carrefours jeunesse-emploi, a network of organizations disseminated over the entire province of Quebec dedicated to the employment of young adults aged 16 to 35 .

The goal of this research is to document the various strategies utilized by professionals in these organizations in building their own coaching practices with young adults that are removed from the labour market. More specifically, we sought understand the means by which these professionals coach youths to lead them to employment participation by investigating the type of activities and the processes involved. We also attempted to determine strengths and difficulties in discharging their duties, in the relationships they establish with their youthful coached clientele and with other stakeholders in the implementation of public employment policies (businesses, public employment services, training providers, etc.) Findings presented in this article refer more specifically to the professional providers' views on issues related to pre- or employment coaching, and their attitudes and know-how as revealed by a review of their practice, which is situated at the crossroads of social work, training, and employment assistance.

\section{Materials and Methods}

This study is based on a sociohistorical analysis model applied to social policies where these are considered a result of interactions between social agents. This model focuses on the dynamics of policy production, and includes the role of agents responsible for its application in a culture where 
public action is being decentralised and governments are cutting expenses (Guillemard, 1986). The present implementation analysis, because it centers on the processes that underlie the everyday application of the intent of public policies, shares this perspective (Lennon \& Corbett, 2003; Perret, 2008).

While both are associated with program evaluation, policy implementation analysis differs from policy impact analysis in that it is less concerned with the effects of a program and more with how the program is carried out in the field, which procedures and actions are used to implement it, and the effect of its application as perceived by the actors in the implementation process. Some policy implementation analysis studies are inspired by the trend in street-level research, an especially useful perspective when analysing human services policies (Brodkin, 2003; Lipsky, 1980). Street-level research is based on the initial proposition that public human services polices translate into a set of routine actions, daily decisions, and exercises in judgement by front line workers whose responsibility it is to provide services to the persons covered by the policy. In this approach, front line workers or agents pass judgement and make decisions about citizens they serve. As field agents, they face a complex reality that public deciders can only partially envision. Variations are observed - substantial gaps, at times between the official intent of a policy, on the one hand, with its train of departmental guidelines, procedures manual and other implementation measures, and on the other hand, the strategies actually employed by agents in the field. In this case however, the gaps "are not being considered dysfunctional, a priori, [...] but rather as an expression of field agents' freedom and responsibility." (free translation, Perret, 2008, p.8).

Our research follows this trend in analysis, with a goal to increase understanding of the dynamics involved in the coaching function being carried out by professional workers in the Carrefours jeunesse-emploi network in the Québec City/Charlevoix region. To that end, we focused our research effort on the role and influence exercised by professionals in these organizations rather than examine the effect of any particular participation measure or mechanism.

Carrefours jeunesse-emploi, which emerged in the early1990s, were established as the core of various youth-oriented employment participation mechanisms and processes in the province of Québec (Assogba, 2000; Assosgba \& Turcotte, 1996), as well as a focus for government efforts to coordinate partnerships among agencies serving troubled youths (Goyette, Bellot \& Panet-Raymond, 2006). Our study population included all professionals offering individual employment coaching services in the Carrefours jeunesse-emploi agencies, Quebec City/Charlevoix region. Our sample included 24 professionals (20 women and 4 men) distributed in the seven local Carrefours jeunesse-emploi agencies, and formed approximately $30 \%$ of the study population. Among these 24 individuals, eighteen were involved in pre-employment coaching (regular employment assistance services, guidance, business consultation, other services), while the six remaining professionals engaged in coaching functions at work, most often as part of an employment participation project, a work shelter or a supervised traineeship in the workplace, etc., where the youth is supervised in the execution of specific work tasks.

As seen below, over $50 \%$ of the professionals interviewed have a Masters degree in career counselling and are members of the Ordre des conseillers et conseillères d'orientation du Québec (Figure 1). The next largest group of professionals graduated in social work $(25 \%)$ while smaller categories include Bachelors in psychological re-education (9\%) and in psychology $(8 \%)$. One person among the professionals interviewed ( $4 \%$ of the sample) graduated in social sciences.

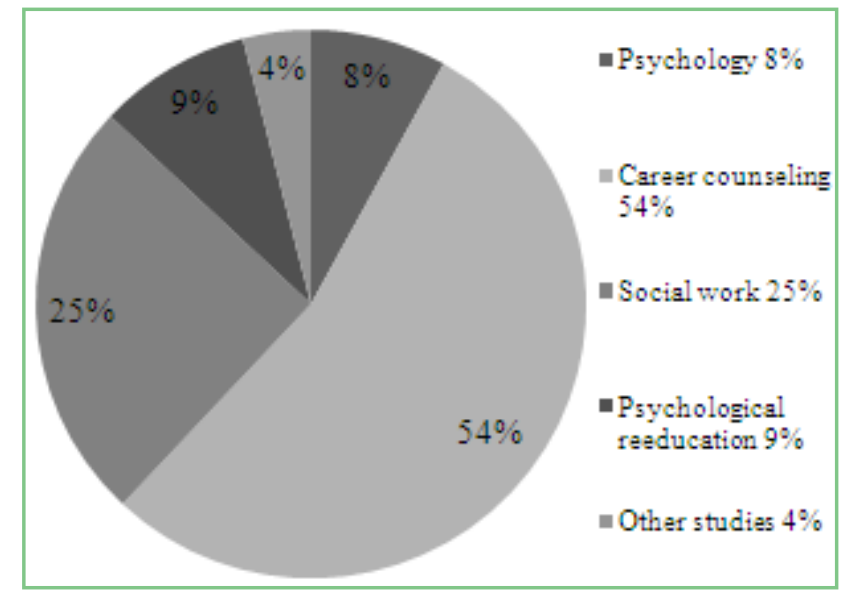

Figure 1. Distribution of respondents according to their field of study.

Nearly three-quarters of professionals interviewed (71\%)totalled less than five years of service, and only $8 \%$ had 10 years or more (Figure 2). Discussions with local organization directors and with the Réseau provincial des Carrefours jeunesse-emploi lead us to believe that the characteristics evidenced by our sample are not diametrically opposite to that of the study population in terms of employment seniority. Most professionals working in Carrefours jeunesse-emploi agencies in the Quebec City region have less than five years of service in the organization.

This mainly qualitative study employed semi-directed interviews that focused on respondents' job description and day-to-day responsibilities; their description and assessment of verbal and other interactions with youths; and views concerning the limitations and challenges perceived in coaching youths who have trouble with labour market participation.

A literature review enabled us to identify a number of coaching practice indicators, which led us to design a content analysis model in which these predetermined categories could be added to those resulting from a more inductive analysis of our material. Performed using data analysis software N'Vivo, the analysis was able to identify 
commonalities and discrepancies in the professionals' expressed views concerning issues and know-how associated with employment coaching practices.

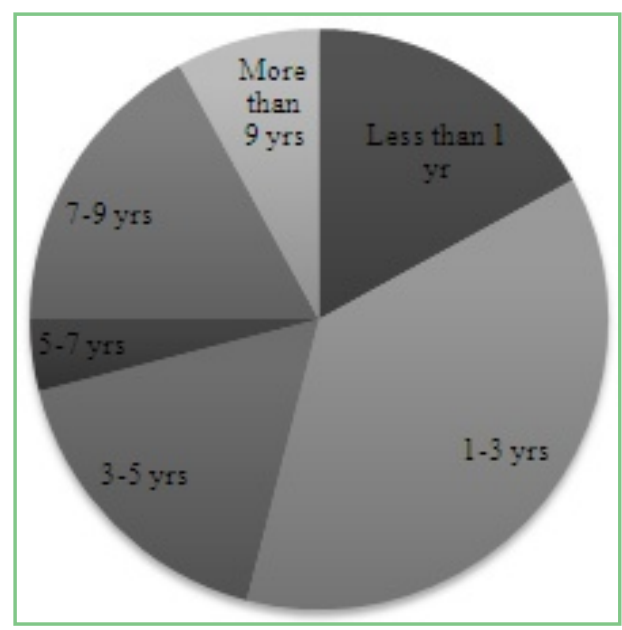

Figure 2. Distribution of respondents according to years of service.

A number of limitations are attached to our study, specifically sample composition, data maintenance, and the strategy used to analyse collected data. Taking into account that our sample was made up of volunteer respondents, we did not discriminate among contributions from individuals who may all be engaging in coaching practices within the Carrefours jeunesse-emploi, but with different responsibilities, duties, and roles. It can be argued that people's views concerning issues and know-how associated with employment coaching practices can vary according to their position within their agency. A major limitation of our study was the small sample size which did not permit us to shed light on common and divergent elements in the views expressed by professionals; either according to their positions or according to the agencies where they work. Furthermore, our analysis did not allow a determination of variability by gender of views concerning these coaching activities. While the findings reported in the following section provide interesting knowledge about coaching practices in Carrefours jeunesse-emploi agencies, they provide only a partial overview.

\section{Results}

On the whole, analysis performed on participant interviews pointed to three basic attitudes they favour when implementing coaching practices: 1) being there to help young adults know themselves and identify what they wish for themselves; 2) respecting their pace in defining and reaching their goals, and 3) being careful not to take action in their stead. These attitudes translate into two types of professional know-how or competencies: (1) creating a bond, and (2) leading young clients to take action.

\section{Bonding or the Capacity to Establish a Significant Relationship with Youths Being Coached}

Analysis of collected interviews indicates that establishing a significant relationship with young clients undoubtedly requires an investment of time and effort by coaching providers. One respondent describes how professionals meet the need to reach their young clients, create a bond, and link with them, as "finding the drive to reach out to them". Various strategies are used by the respondents to create this rapport, ranging from free discussion on aspects not related to employment participation, to making themselves available outside the organization's regular hours of operation.

A number of participants revealed that in sessions with young adults, they explored a number of more personal subjects, outside the issue of employment, so as to establish some form of closeness. Conversations can be about anything in these sessions. Their purpose is not just to talk about employment but to talk about anything that matters. "Anything can be the basis for establishing a link with them. Getting to know them better. Is there something else going on? Have they had their hearts broken? Well then, that's when things can develop, really." According to study participants, these free conversations allow the young clients to see the professionals from a different angle. "So then he sees me differently. He sees I'm more accessible to him than a counsellor sitting in his office, front to front." Chatting informally and having a bit of fun with young clients being coached fosters bonding. The pleasure derived from the sessions becomes a key ingredient in creating a successful bond. "We have fun, we laugh a lot! This reaches the youths. They get to have some fun. Sometimes we'll be giving a workshop and we'll get side-tracked. We make a few jokes. We leave some space for pleasure." Going even further, some of the professionals stated they were open about being available outside working hours and provided their cell phone number for any emergency. "Even when they don't call me, I feel that knowing I'm there and available, it's reassuring for them."

Parallel to these prevalent views on the importance of developing a significant relationship with youths being coached, especially by going beyond the formal structure for delivery of professional services, divergent views from a minority of respondents were also noted. Some of them felt it was important to provide a tightly controlled environment to youths being coached, which refers to another conception of the attitudes and know-how required in coaching young adults towards employment. "It requires some discipline. For others, maybe they don't feel like exercising that much discipline. I know that some of my colleagues don't provide as tight guidance as I do."

The professionals' task is a delicate one: to encourage a young adult's self-expression and discovery of their inclinations, and also to encourage them to be realistic in their expectations. They must be made aware of the realities of a working life without having their aspirations discounted. Getting young adults to pare down their criteria and accept a compromise is an inherent challenge in this occupation. "They will request a short training program, but express diplomas are also short in value. Or they want part time training, and they want evening classes. So then it's 
more difficult." Study participants reported they were often confronted with rather unrealistic wishes entertained by young people being coached. "Sometimes they're not super realistic [...] because they want good wages but they don't want to go to school very long: I'd like to take a one-year course and earn fifty thousand." Therefore, while it is essential that youths' wishes be taken into account when establishing a bond with them, it can also become a barrier, especially if the coaching provider becomes aware of a specific need that is not taken into account in the young person's wishes. Coaching becomes more complex in that situation and progress can even come to a halt. "It's a challenge because this aspect is very bothersome to us, as case workers and as coaches. When you know you're coaching someone who's only going to fail."

As well, study participants were vocal about the need to respect the pace that youths will take in their process towards employment participation. In their view, professionals must come to terms with the fact that there will be backtracking, and complete stops, while resisting the urge to go "ahead" of the young adult or "do things in their stead". Several study participants emphasized the importance of letting youths understand that there is no pressure for them to engage in a particular path, that the coach merely sets out their options, without imposing any of them.

When questioned further on the importance they give to following the pace of youths being coached, professionals were unanimous in associating the "threat" to youths in insisting that they get a process going with an "authoritarian attitude" that precludes, in their view, the pursuit of a genuine coaching process. This view, abundantly expressed in the professionals' responses, seemingly refers to the idea of establishing a clear distinction between themselves and the public employment service officers or other authority figures (parent, teacher, etc.). "Myself, I have no authority. I'm not at school so I don't demand that they come here necessarily. I am not a parent, so that can sometimes be useful. I don't require anything; I am not in a position of authority, so it's easier. I can gain their trust more quickly."

However, some respondents mentioned that adhering to a youth's own pace must not lead to prolonged inaction, which illustrates the importance of being able to judge when it's time to "nudge" the client in the direction of employment participation. "You've got to work! Sometimes you have to dance with your client and sometimes he or she has to do the dancing. You tell them: Listen; now you have to get on with things. We're done with following you. You are now going to follow me for a while." Furthermore, consideration given to clients' pace sometimes leads to termination of a coaching relationship, when the professional observes that a client is not entirely ready to engage actively in a process. "See here, you have to do your bit. Do what you have to do and call me back. Six months later, he calls me back. OK, come in to see me! So having that kind of latitude allows us to really help them."

A final factor in bonding is the professional's ability to lead youths to trust the coaching process and to feel they know where they're going. Indeed, several participants felt it is important to maintain credibility with youths so they will be inspired to personally invest in the process and show up for future appointments. So the concern with bonding must be paralleled by articulated and structured practices that ensure the effectiveness of the coaching process.

If people feel we are going to help them, they come in for their meetings. But if I'm all over the place during my meetings, if I don't know where I'm going, if I let people vent on just any subject, and they leave here not knowing what I can do to help them, I'm not sure they'll feel like coming in to waste their time with me, the next time.

\section{The Activation Process}

As mentioned earlier, data collected in our study show that Carrefours jeunesse-emploi professionals agree that it's important that they do not act in their clients' place, but rather let them be as independent as possible, and become stronger actors in their own lives. In addition, taking charge of the youths they are coaching can easily lead to a burn-out. "The other method, with greater taking charge, is often more draining, and it's not that efficient either."

The ability to establish a diagnostic of the problem situation creating a barrier to employment participation is generally dependent on the ability to understand the actual person with participation issues, know what their needs are, and foresee their possible difficulties in dealing with their "participation plan". In our study, participants spoke about the competencies or skills needed in developing an action plan that will lead their client to participate in the labour market, or improve their employability status.

The challenge here continues to be the professionals' ability to determine what suits the young person, not only in the choice among available activities and program, but also concerning the way in which these are put in application. This requires a thorough knowledge of the various programs, measures and activities offered in the jurisdiction by public or community networks active in employability development. "A counsellor is a person who is aware of traineeship opportunities, employability programmes, and everything else that is available. When you have those tools, you can offer a real coaching experience to people."

Assisting a young person with their activation process can also take the form of intercession or mediation between the youth being coached and potential employer. Professionals then take on a promotional role for the youth's abilities and potential.

For sure, if that person doesn't have someone who will give a little push in the right direction, often it doesn't work out. So I will contact employers, and tell them: You are going to meet so and so, and I must tell you that this person at first sight might seem to have this or that set of characteristics but he's a person who is worth knowing. I've had occasion to spend time with him and I want to draw your attention to this 
or that particular quality of his. It's like giving them references before we're asked to do so.

In another vein, the ability to maintain a good network of contacts among potential employers and traineeship venues within the local community is also part of employment coaches' skills set. Many of them find it necessary to solicit local employers and trades people for traineeship placements and jobs. For instance, a professional might call on a local craftsman because his trade is proving interesting to a specific youth. He is told of the interest of a young person who is receiving the agency's services, and the professional can arrange for them to connect. Making the connection usually happens informally and is directly creditable to the professional's network of contacts in the community.

Participants interviewed also mentioned that deciding what might work best for a specific youth requires a certain flair, an eye for it, as well as the ability to recognize which clients are really serious about wanting to enter a process leading to employment participation. Needless to say, many of the youths who are eligible to participate in coaching measures and programs are living in precarious circumstances. Therefore, an employability process that provides access to an allowance will be more interesting to them than one with objectives and procedures as in the case of special coaching measures. "He comes here five hours a week and I feel that's enough for the time being... I have to exercise judgement and tell myself not to ask anything more of him right now, or I'm going to lose him."

One of the key competencies of a professional wishing to assist a youth to get into action and improve his chances for employment participation, lies in being able to suggest an employability measure that is a good match for the youth's individual reality, how far he has progressed in his chosen path and the pace of his progress. "I won't select this or that traineeship because it's not suitable for my participant. If the conditions of a program are contrary to what I feel is indicated for his welfare, I certainly won't use it."

Furthermore, from the moment a coached youth is registered with public employment services, the Carrefour professional is interacting not only with the public service agent in charge of the youth's file but with a number of professionals who are part of a complex line of authority that is inherent to public institutions. This requires that the professional have a capacity to propel information and influence the processing of individual files within complex organizations where many actors interact. "Administratively speaking, it can take an awfully long time in some cases, for certain requests." Similarly the volume of documentation to be provided and the complex nature of some procedures require the professional to be efficient in speeding their request through so that delays do not interfere with the coaching process.

Aside from this, procedures leading to the admission of youths in a coaching project are not only complex but they refer to strict eligibility criteria that can jeopardize the youth's participation in a project implemented by the Carrefour jeunesse-emploi. In some cases the professional's competence has to include not only a capacity to bring out the necessity or pertinence of providing access to a program for a specific youth, but also to defend this pertinence before a number of actors involved in the "file" and enjoying various levels of authority within the public system. "I would assess the needs, ok, this is it. Procedures take a long time; a month would often go by before the youth was accepted. Well now, he can't wait a whole month with no income, and he can't take a full-time job, to remain eligible as a participant. Because if he has a full-time job, he doesn't have the need, and then Emploi-Québec doesn 't accept him."

"Sometimes we have to persuade Emploi-Québec as to pertinence. In some cases it's obvious, when they don't have a high school diploma, and such, then it's easy to persuade them to admit these youths in a program. But take the case of a young person with a university education, who had the intellectual capacity to acquire professional training; it does not necessarily follow that he has the ability and the social skills to find a job. So sometimes it's a little more difficult."

Finally, a number of respondents felt there were consequences associated with the complexity of the youths' objective and subjective living conditions, and with the difficulty in accessing psychosocial counselling in the local jurisdiction. Indeed, extending the range of employment assistance services so that service delivery is increasingly directed to social participation in general, requires competencies that are more directly related to individual social intervention. "We would need to be experts in everything. We're not, but that's the kind of pressure we sometimes feel in our reality. Because within public services, it's difficult to provide our kind of coaching."

\section{Conclusions}

The findings herein inform us of the views of coaching professionals employed by Carrefours jeunesse-emploi in one region in the province of Quebec, regarding the competencies and attitudes that contribute to the effectiveness of coaching practices. These results are consistent with that of other studies conducted in France and in the United States on the role and influence of people involved in the delivery of employment services to troubled youths.

As also revealed by Guele, Sibeud, Rabeyrin and Devries (2003), when troubled youths are the target of coaching towards labour market participation, employment coaching can hardly be considered in isolation from more general coaching toward social participation, and this in turn depends on establishing and sustaining a relation of trust between the coach and the young person being coached. It is difficult for Carrefours jeunesse-emploi professionals to limit their work to technical assistance in searching for a job. Theses coaches are indeed working in the role of social support workers whose job often ends up being to ensure that preconditions to a job search are in place, in addition to actually coaching of youths as they search for employment. 
In this study, as in several others (Ardenti, 1995;Defalvard, Brun \& Thibault, 2008; Houzel, Outin \& Ramaux, 2000; Gratadour \& Mansuy, 2007) findings point to the fact that when public employment policies are implemented through a coaching process, front line workers are required to reinvent for each client a path that will make it easier for them to start participating in the labour market. But the work that translates as a constant adjustment between services, measures and programs provided by the policy, and the needs, expectations and aspirations of at risk youths, is not described anywhere. In these circumstances as nowhere else, professionals are creating new social practices and deploying unprecedented specific competencies.

In our estimation, findings in this study show the pertinence of furthering our current knowledge of the influence of participation professionals in implementing employment policies. Programs, services and measures are used as instruments in the coaching process. In fact, this process is spoken of as being deployed in a dyad where targeted categories of population are in constant dialog and cross-influence with the workers required to use these services, measures and programs to foster sustainable employment participation of people at risk or excluded in some way. Development of a body of knowledge on the impacts of public employment policy depends on the development of knowledge about the influence of professionals in the field who are involved in delivering employment coaching services.

\section{REFERENCES}

Ardenti, R. (1995). Les politiques publiques de l'emploi et leurs acteurs: des repères pour l'évaluation. France: Presses universitaires de France.

Assogba, Y. (2000). Insertion des jeunes : organisation communautaire et société. L'expérience fondatrice des carrefours Jeunesse-Emploi au Québec. Québec : Presses de l'Université du Québec. Retrieved from

http://www.ciriec.uqam.ca/pdf/numeros_parus_articles/3301/ES-3 301-13.pdf

Assosgba, Y., \& Turcotte, D. (1996). Insertion de l'autre jeunesse dans l'Outaouais : le cas du Carrefour Jeunesse-Emploi. Québec : Université du Québec à Hull.

Austin, M., Johnson, M.A., Chow, J., De Marco, A., \& Ketch, V. (2009). Delivering Welfare-to-Work Services in County Social Services Organizations: An Exploratory Study of Staff Perspectives. Administration in Social Work, 33(1), 105-126. doi:10.1080/03643100802508668

Baron, C., Bureau, M.-C., Leymarie, C., \& Nivolle, P. (1995). L'action des intermédiaires: animation du marché local du travail, mobilisation de la main-d'oeuvre, médiation sociale. In R. Ardenti (Ed.), Les politiques publiques de l'emploi et leurs acteur: des repères pour l'évaluation (pp. 213-233). France: Presses universitaires de France.
Baron, C., Dugué, E., \& Nivolle, P. (2005). La place des jeunes dans la Cité: de l'école à l'emploi. France: Les Éditions L'Harmattan.

Bell, H. (2005). Caseworkers'Assessment of Welfare Reform : Report from the Front Lines. Journal of Human Behavior in the Social Environment, 12(2-3), 243-259.

doi: $10.1300 / \mathrm{j} 137 \mathrm{v} 12 \mathrm{n} 02 \_13$

Bessy, C., Eymard-Duvernay, B., Gomel, B., \& Simonin, B. (1995). Les politiques publiques d'emploi : le rôle des agents locaux. In R. Ardenti (Ed.), Les politiques publiques de l'emploi et leurs acteur : des repères pour l'évaluation (pp. 3-34). France: Presses universitaires de France.

Bompard, J.-P., Daubech, D. (2000). «Introduction ». In D. Gélot \& P. Nivolle (Eds.), Les intermédiaires des politiques publiques de l'emploi (pp.7-14). France: La documentation française.

Brodkin, E. Z. (1997). Inside the Welfare Contract: Discretion and Accountability in State Welfare Administration. Social Service Review, 71(1), 2-33.

Retrieved from http://www.jstor.org.acces.bibl.ulaval.ca/stable/pdf plus/30012604.pdf?\&acceptTC=true\&jpdConfirm=true

Brodkin, E. Z. (2003). Street-level research : Policy at the front lines. InM. C. Lennon, \& T. Corbett (Eds.), Policy into Action. Implementation Research and Welfare Reform (pp.141-163). Washington : Urban institute Press.

Bullock, E.H. (2004). From the Front Lines of Welfare Reform: An Analysis of Social Worker and Welfare Recipient Attitudes. Journal of Social Psychology, 144(6), 571-588. doi: 10.3200/SOCP.144.6.571-590

Crif Formation \& Conseil. (2005). L'accompagnement socio-professionnel vers et dans l'entreprise. Retrieved from http://prao.centredoc.org/opac/doc_num.php?explnum_id=186

Defalvard, H., Brun, F., \& Thibault, M. (2008). Les pratiques de l'accompagnement dans et vers l'emploi au sein de différents contextes institutionnels d'acteurs. France: Centre d'Études de l'Emploi.

Gélot, D., \& Nivolle, P. (2000). Les intermédiaires des politiques publiques de l'emploi. France : La documentation française.

Goyette, M., Bellot, C., \& Panet-Raymond, J. (2006). L'insertion des jeunes en difficulté : une problématique complexe. In M.Goyette, C. Bellot, \& J. Panet-Raymond (Eds.), Le projet Solidarité jeunesse: dynamiques partenariales et insertion des jeunes en difficulté (pp. 5-16). Québec : Presses de l'Université du Québec.

Guele, J., Sibeud, C., Rabeyrin, J., \& Devries, P. (2003). L'accompagnement social en question. Retrieved from http://static.canalblog.com/storagev1/dimacopoulos.canalblog.com /docs/Rapport_pratiques_accompagnement.pdf

Guillemard, A.-M. (1986). Le déclin du social. France : Presses universitaires de France.

Gratadour, C., \& Mansuy, M. (2007). Sous-traiter l'accompagnement des chômeurs : éléments d'évaluation. Travail et emploi, 112, 21-34. Retrieved from http://travailemploi.revues.o $\mathrm{rg} / 2250 \#$ text

Hagen, J.-L., \& Owens-Manley, J. (2002). Issues in Implementating TANF in New-York: The Perspective of Frontline Workers. Social Work, 47(2), 171-182. doi : 10.1093/sw/47.2.171 
Hagen, J.-L., \& Wang, L. (1993). Roles and Functions of Public Welfare Workers. Administration in Social Work, 17(2), 81-103. doi : 10.1300/J147v17n02_06

Herd, D., Mitchell, A., \& Lightman, E. (2005). Rituals of Degradation: Administration as Policy in the Ontario Works Programme. Social Policy and Administration, 39(1), 65-79. doi : $10.1111 /$ j.1467-9515.2005.00425.x

Hjörne, E., Juhila, K., \& Van Nijatten, C. (2010). Negociating Dilemnas in the Practices of Street-Level Welfare Work. International Journal of Social Welfare, 19(3), 303-309. doi: $10.1111 / \mathrm{j} .1468-2397.2010 .00721 . \mathrm{x}$

Houzel, Y., Outin, J.-L., \& Ramaux, C. (2000). Travail, logiques d'action et sens du travail des intermédiaires de l'emploi. In D. Gélot \& P. Nivolle (Eds.), Les intermédiaires des politiques publiques de l'emploi (pp.107-138). France: La documentation française.

Leclerc, C., Filteau, O., \& Bourassa, B. (2002). Les savoirs d'expérience développés dans les centres locaux d'emploi. Québec : CRIEVAT Laval. Retrieved from http://www1.sites.fse.u laval.ca/fichiers/site_crievat/documents/Cahiers/oeuvrer.pdf

Lennon, M.C., \& Corbett, T. (2003). Policy Into Action. Implementation Research and Welfare Reform. Washington: Urban Institute Press.

Lipsky, M. (1980). Street-level Bureaucracy: Dilemmas of the Individual in Public Services. New York : Russel Sage Foundation.

Livermore, M., \& Neustrom, A. (2003). Linking Welfare Clients to Jobs: Discretionary Use of Worker Social Capital. Journal of Sociology and Social Welfare, 30(2), 87-103. Retrieved from http://web.b.ebscohost.com.acces.bibl.ulaval.ca/eh ost $/$ pdfviewer $/$ pdfviewer?vid=3\&sid=bf7c856e-0664-4320-8f7d-9 c17dc0af197\%40sessionmgr111\&hid=112

MacDonald, C., \& Marston, G. (2006). Room to Move? Professional Discretion at the Frontline of Welfare-to-Work. Australian Journal of Social Issues, 41(2), 171-182. Retrieved from http://web.a.ebscohost.com.acces.bibl.ulaval.ca/ehost/pdfvie wer/pdfviewer?sid=991a9de0-760d-4e83-8d09-d947050fc988\%40 sessionmgr4002\& $\&$ id $=4 \&$ hid $=4107$

Meyers, M.K., Glasser, B., \& MacDonald, K. (1998). On the Front Lines of Welfare Delivery: Are Workers Implementing Policy Reform? Journal of Policy Analysis and Management, 17(1),1-22. doi: 10.1002/(sici)1520-6688(199824)

Perret, B. (2008). L'évaluation des politiques publiques. Retrieved from http://www.cedip.equipement.gouv.fr/IMG/pdf/pol itiques_publiques_cle7b1a3a.pdf

Provencher, Y., Émond, P., \& Tremblay-Roy. (2010). Pratiques d'accompagnement dans les carrefours jeunesse-emploi de la région de Québec/Charlevoix. (Rapport No. 978-2-89497-082-9). Québec : Centre de recherche JEFAR, Université Laval.

Provencher, Y. (2004). L'aide sociale au Nouveau-Brunswick. Évolution historique et perspectives contemporaines. Canadian Review of Social Policy, 54, 18-33.

Provencher, Y. (2007). Aide sociale au Nouveau-Brunswick : le discours des personnes assistées sociales au sujet de leurs rapports avec leur gestionnaire de cas. Canadian Review of Social Policy, 59, $56-75$

Provencher, Y. (2008). Kept Away From Getting Out of Welfare. Experiences of Social Assistance Recipients in New-Brunswick, Canadian Social Work Review. Canadian Social Work Review, 25(1), 55-70.

Provencher, Y., \& Richard, M.-C. (2010). Public Employment Policy Professionals in Industrialized Countries: Different Contexts and Similar Practices. Canadian Review of Social Policy, 63, 50-62.

Provencher, Y. (2013). L'accompagnement vers l'emploi dans les carrefours jeunesse-emploi : la politique d'insertion à l'épreuve du terrain. Regards sur le travail, 9(2), 1-14.

Riccucci, N., \& Lurie, I. (2003). Changing the Culture of Welfare Offices: From Vision to Front Lines. Administration and Society, 34(6), 653-677. doi :10.1177/0095399702239169

Sandfort, J. (2000). Moving Beyond Discretion and Outcomes: Examining Public Management from the Front Lines of Welfare System. Journal of Public Administration Research and Theory, 10(4), 729-756. Retrieved from

http://www-test.hhh.umn.edu/people/jsandfort/pubs/peer_reviewed /examine_pubmgmt_welfare.pdf

Weissert, C. (1994). Beyond the Organization : The Influence of Community and Personal Values on Street-Level Bureaucrats' Responsiveness. Journal of Public Administration Research and Theory, 4(2), 225-254.

Retrieved from http://jpart.oxfordjournals.org.acces.bibl.ulaval.ca/ content/4/2/225.full.pdf + html 